\section{The Prevent Alcohol and Risk-related Trauma in Youth (P.A.R.T.Y.) Program: Evaluation Results From Saskatoon, Canada}

\section{Dear Editor:}

Transportation collisions on public roadways are a major cause of injury-related death and disability in Saskatoon Health Region (SHR). ${ }^{1,2}$ The 15 to 24 year age group in SHR had the highest mortality rate from transportation between 1995 and 2006. ${ }^{1}$ One program aimed at reducing preventable injuries and deaths among youth is the Prevent Alcohol and Risk-related Trauma in Youth (P.A.R.T.Y.) Program. The P.A.R.T.Y. Program is a licensed, national one-day in-hospital injury awareness and prevention program for grade ten students. Although the P.A.R.T.Y. Program is widely used in Canada and several other countries, there are few evaluations that have been conducted on the effectiveness of the program. The purpose of our study was to see if there was a change in youth's attitudes and knowledge around risk-taking behaviour after participation in the SHR P.A.R.T.Y. Program.

Our evaluation followed a pre-post design with no control group. ${ }^{3}$ Participants were grade ten students from 17 schools ( 8 urban and 9 rural) in SHR who completed the P.A.R.T.Y. Program between November 2006 and June 2008. Students who participated in the P.A.R.T.Y. Program were administered a questionnaire both one week prior to and one week after participation in the program. The questionnaire was a mix of 12 attitudinal questions on risk and behaviour and 9 knowledge-based questions about injury and risk. Questionnaires were matched pre- and post-test. For attitudinal and knowledge questions, descriptive statistics were computed. Paired sample t-tests were conducted on all questions to compare the preand post-test scores.

A total of 408 students (285 from urban schools and 123 from rural schools) were included in the analysis. For attitudinal questions, all of the post-test ideal percentage scores were higher compared to the pre- time period. Table 1 shows that there was a statistically significant increase in the percentage of ideal answers in the post-test compared to the pre-test time period for all schools combined (T-value $-7.415, \mathrm{p}<0.001$ ), all urban schools combined (T-value -6.176, $\mathrm{p}<0.001$ ) and all rural schools combined (T-value -4.117, $\mathrm{p}<0.001$ ). For knowledge questions, the percentage answered correctly increased from pre- to post-time periods. Table 1 shows that there was a statistically significant increase in the percentage of correct answers in the post-test compared to the pre-test questions for all schools combined (T-value $-17.52, \mathrm{p}<0.001$ ), all urban schools combined (T-value $-14.705, \mathrm{p}<0.001$ ) and all rural schools combined (T-value -9.504, $\mathrm{p}<0.001$ ).

Injuries are a major cause of death and disability for youth ages 15 to 24 in Canada, and in particular in the province of Saskatchewan. Given that transportation and alcohol use are two major contributors to these deaths, prevention programs that target these factors are an important component of reducing injuries. While there were limitations in the study design (i.e., no comparison group, self-report survey data, inability to calculate response rates due to lack of denominator data, and a short time period between pre- and post-test questionnaires), the results suggest that the SHR P.A.R.T.Y Program is having a positive impact in the short term in improving students' attitudes and knowledge with regard to risk-taking behaviour.

Tanis Kershaw, MPH, Epidemiologist, Winnipeg Regional Health Authority, Winnipeg, $M B$

Josh Marko, MPH, Population and Public Health, Saskatoon Health Region, Saskatoon, SK

\section{REFERENCES}

1. Neudorf C, Marko J, Wright J, Ugolini C, Kershaw T, Whitehead S, et al. Health Status Report 2008: A Report of the Chief Medical Health Officer. Saskatoon, SK: Saskatoon Health Region, 2009.

2. Saskatchewan Ministry of Health. Saskatchewan Comprehensive Injury Surveillance Report 1995-2005. Regina, SK: Government of Saskatchewan, 2008

3. Rossi PH, Freeman HE, Lipsey MW. Evaluation, $6^{\text {th }}$ edition. Thousand Oaks, CA: Sage Publications Ltd., 1999.

Table 1. $\quad$ Paired Sample Results for All Attitudinal Questions and All Knowledge Questions Combined by All Schools, Urban and Rural

\begin{tabular}{|c|c|c|c|c|c|}
\hline & $\begin{array}{c}\text { Pre-test } \\
\text { Mean (SD) }\end{array}$ & $\begin{array}{l}\text { Post-test } \\
\text { Mean (SD) }\end{array}$ & Difference of Means & T-value & p-value \\
\hline $\begin{array}{l}\text { Attitudinal Questions* } \\
\text { All schools }(n=408) \\
\text { Urban schools }(n=285) \\
\text { Rural schools }(n=123)\end{array}$ & $\begin{array}{l}7.76(2.68) \\
7.63(2.64) \\
8.07(2.76)\end{array}$ & $\begin{array}{l}8.73(2.80) \\
8.55(2.84) \\
9.15(2.69)\end{array}$ & $\begin{array}{l}0.97 \\
0.92 \\
1.08\end{array}$ & $\begin{array}{l}-7.415 \\
-6.176 \\
-4.117\end{array}$ & $\begin{array}{l}<0.001 \\
<0.001 \\
<0.001\end{array}$ \\
\hline $\begin{array}{l}\text { Knowledge Questions† } \\
\text { All schools }(n=408) \\
\text { Urban schools }(n=285) \\
\text { Rural schools }(n=123)\end{array}$ & $\begin{array}{l}5.91(1.97) \\
5.93(1.96) \\
5.85(2.00)\end{array}$ & $\begin{array}{l}7.42(1.71) \\
7.48(1.74) \\
7.30(1.67)\end{array}$ & $\begin{array}{l}1.51 \\
1.55 \\
1.45\end{array}$ & $\begin{array}{l}-17.52 \\
-14.705 \\
-9.504\end{array}$ & $\begin{array}{l}<0.001 \\
<0.001 \\
<0.001\end{array}$ \\
\hline $\begin{array}{l}\text { * Mean scores could range } \\
\text { answered ideally. } \\
\dagger \text { Mean scores could range } \\
\text { answered correctly. }\end{array}$ & $\begin{array}{l}\text { 12, with } 12 i \\
9, \text { with } 9 \text { ind }\end{array}$ & $\begin{array}{l}\% \text { of the que } \\
00 \% \text { of questi }\end{array}$ & $\begin{array}{l}\text { re answered ideally and } \\
\text { answered correctly and }\end{array}$ & $\begin{array}{l}\text { ing that } n \\
\text { ting that } r\end{array}$ & ons were \\
\hline
\end{tabular}

